\title{
Declining sikh space on the religious and political landscape of India
}

\begin{abstract}
This study is devoted to highlighting the temporal trends and spatial variations in the concentration and growth of the major religious groups in India with special reference to the Sikh population. Such studies are gaining importance with the increasing penetration of both the religion and castecomposition in the political environment of the country. Although religious and caste interventions in politics are prevalent in all the elections, these become stronger as we move down from Parliamentary to Panchayat elections in which the voting pattern changes in favour of religion and caste groups. It has been observed that the share of Muslim population increased by 5.96\% between 2001 and 2011, while it declined in the case of all other communities and the maximum decline $(-8.02 \%)$ was noticed in the case of the Sikh population with the lowest share among all the major religious communities in India. The Sikh population also recorded the lowest growth rate of $8.42 \%$ against $24.65 \%$ and $16.76 \%$ witnessed by Muslims and Hindus respectively between 2001 and 2011 . The study is based on the religious data released by the Census of India.
\end{abstract}

Keywords

Religion $\bullet$ sikh $\bullet$ hindu $\bullet$ muslim $\bullet$ election $\cdot$ migration

(c) University of Warsaw - Faculty of Geography and Regional Studies

Introduction

Although religion is a personal matter, the religious identity of an individual in India is often expressed socially (Ahmad 1999). Apart from its key role in understanding the current socio-political pulse of a region, the study of religious composition also helps to understand the concentration, growth and migration patterns (voluntary or forced) of communities. The partition of British India in 1947 was primarily based on religion and resulted in one of the greatest and most painful migrations in human history in which millions of Muslims, Hindus and Sikhs had to cross the newlycreated international boundaries. Even within India, a large number of Sikhs migrated to Punjab from other states of India after the 1984 riots. In a short period from late 1989 to early 1990 an astounding number (over 58,000 ) of Kashmiri Pandits families fled their homeland and resettled largely in Jammu city, the winter capital of the state of Jammu and Kashmir and few other Indian cities (Singh 2015).

Religion does influence the totality of the way of life of its adherents through its impact upon their socio-cultural behaviour, economic expressions, political ethos and legal institutions (Chandna 2006). In a democratic country like India, where religious bonds are very strong, the role of religious identity cannot be ignored in the voting behaviour of the people. Even within religious groups, there are divisions based on castes and subcastes, all of which have their own role in decision-making and building pressure groups to influence the political scenario of the areas. Therefore, all the political parties take note of these pressure groups while fighting elections.

Ever since the emergence of the first political state, there seems to have been a correlation between political administration

\author{
Harwant Singh Mangat $\mathbb{C}^{1}$, \\ Shaik Iftikhar Ahmed $\mathbb{C}^{2}$, \\ Lakhvir Singh Gill $\mathbb{C}^{3}$ \\ 'Department of Geography, Punjabi University, \\ Patiala, India \\ e-mail: hsmangat@rackeys.com \\ 2Population Research Centre, Centre for Research in \\ Rural and Industrial Develooment, Chandigarh, India \\ e-mail: msititikhar@gmail.com \\ 3University College, Ghanaur, Patiala, India \\ e-mail: lakhvirsgill@gmail.com \\ Received: 30 October 2020 \\ Accepted: 8 March 2021
}

and religious systems (Chandna 2006). Religion and caste are also taken into account in the constitution of both the internal structure of a political party and in its fielding of candidates in elections. Political pressure exerted by a religious community/ caste is directly related to the voting strength of that religious/ caste group. As electoral politics became increasingly competitive by 1970 s, with the rise of backward castes, their manipulation became widespread among political parties (Teltumbde 2015). In recent years "Saffron Demographers" have utilized 'demographic data to achieve non-demographic objectives' (Anwaruzzaman 2010). Taking note of the growing numerical strength of Muslims after the release of religious data by the Census in 2015, the Sangh Parivar (Sangh Parivar refers to Hindu nationalist organizations affiliated to Rashtriya Swayamseyak Sangh called RSS) and especially the Vishva Hindu Parishad (VHP is a religious organization of Hindus based on Hindu nationalism) began to raise the issue of Ghar Wapsi (come back home). A drive by Hindu nationalist organizations to "reconvert" Muslims and Christians to Hinduism is essentially about shoring up the numerical strength and political power of the "Hindu community" and has little connection to religious persuasion; they feel that the number of Hindus is decreasing and, if left unchecked, "others" by sheer force of procreative factors would take over the Hindus' motherland (Katju 2015). It is asserted that the population of Muslims is growing so quickly that the day is not far off when they will outnumber Hindus and, when this happens, India will automatically become an Islamic country (Mishra 1994). Such claims have, in part, led to the politicization of religious nationalism and fundamentalism in India which have recently become more strident and aggressive (Heredia \& Rudolf 2015). 
This contentiousness has further solidified a strategy of communal polarization which has been quite successful in India's crisis-ridden polity. It brought Modi three terms in office as chief minister after the 2002 Gujrat carnage and also saw the Bhartiya Janata Party (BJP) win 74 seats out of 80 in Uttar Pradesh in the last (2014) Lok Sabha elections (Teltumbde 2015). The Congress party had similar achievements after the 1984 carnage against Sikhs when the party won 414 seats out of 533, setting a new landmark in the electoral history of India. More recently, the state and society in India have become increasingly and violently communal, with communal politics being projected onto the national scene (Heredia \& Rudolf 2015) in ways hitherto unknown. During the recently concluded Lok Sabha elections (2019), the Congress Party upped the ante against the Shiromani Akali Dal in Punjab. Not only did the Party holding an election rally addressed by its President Rahul Gandhi in the epicenter of sacrilege politics, at Bargari, (Bargari is the village in Faridkot District where a few torn pages from the Holly Book (Guru Granth Sahib) were found resulting in widespread discontent and protests by Sikhs in which two people were shot by the police), but it also announced a memorial in the vicinity as homage to those killed in the 2015 police shooting (Khanna \& Garg 2019). Such actions add force to the well-overused adage that politicians in India always try to exploit communal and religious sentiments of people for political gains.

When in power, political parties can use their legislative power to divide the people along religious lines to strengthen their voter base. While commenting on the Citizenship Amendment Act (CAA) passed by the Parliament of India on December 9, 2019, Yadav (2019) has observed that the priority of the government is to arouse sentiments, especially among Hindus, along religious lines for vote-bank politics. Similarly, (Hausing 2019) also highlighted that, in selectively excluding Muslims, the BJP naively assumes that it will draw support from the Assamese people who bore the brunt of the "illegal migrants" (Bangladeshi Muslim migrants). The law that offers citizenship only to nonMuslims sidesteps the real issues for political mileage (Godbole 2019). Likewise, to consolidate her vote bank, Mamta Banerjee, chairperson of the All-India Trinamool Congress party and Chief Minister of West Bengal, organized a massive rally in Kolkata against the amended citizenship law and proposed a National Register of Citizens (NRC). Furthermore, she said that if the Centre plans to implement these proposals in the state, "they will have to do it over my dead body" (Express News Service 2019). The way the NRC and later Citizen Amendment Bill (CAB) were catapulted into the electoral domain through three elections in which the BJP successfully steered and consolidated its agenda of Hindutva, bolsters the argument that the CAB is driven by the desire of a larger electoral payoff as a strategy of political rationality (Roy 2019). Roy has further mentioned that the NRC and $C A B$ have articulated an idea of exclusionary citizenship, to reap electoral advantage for the BJP in successive elections. Similarly, while commenting on CAB, Guru (2019) has observed that this insidious legislation can be seen as a substantial building block for the majoritarian-exclusivist political project of the Hindutva espoused by the ruling Bharatiya Janata Party. It is bitterly disappointing to see our resources, attention and energies being frittered away on far-less urgent but inflammatory issues related to religion, places of worship and even bovine welfare. These may garner votes, but we cannot evade the reality that, unless India's national leadership focuses on economic, industrial, scientific and technological progress, the country will remain backward and firmly anchored in the third world (Parkash 2019).

In this context, studies related to the religious composition and distributional patterns of various religious groups and castes in India become important. This study, therefore, is focused on the changing religious scenario of India with special reference to the Sikh population.

\section{Objective}

The major objective of this study is to analyze the temporal and spatial variation in the concentration and growth of major religious communities in India with special focus on the Sikh population.

\section{Database and methodology}

The study is based on the data relating to religion from the Census of India, particularly for the three decades of 1991 , 2001 and 2011. Since more than $98 \%$ of the total population in India falls into the four religious categories of Hindu, Muslim, Christian and Sikh, the analysis in this study is focused on these four religions only. Further, for the spatial analysis, the study is restricted to the six northwestern states of India, i.e. Punjab, Haryana, Himachal Pradesh, Rajasthan, Jammu and Kashmir, as well as Uttarakhand, Delhi National Capital Territory (NCT) and the Union Territory (UT) of Chandigarh as $93 \%$ of the total Sikh population is concentrated in these north-western states, Delhi NCT and Chandigarh UT. The simple statistical technique of percentages has been applied to interpret the results. Tables have been prepared to analyze and highlight the temporal and spatial variation of the data under study.

\section{Review of literature}

Populations throughout the world are embedded with various kinds of religious beliefs. Even within the same religion, there are sub-sects with their own socio-cultural identity. Religion provides a distinct identity fora religious group which has its own role in the development of inter-religious understanding, relationships, co-operation and even conflicts. Religious groups may also play a role in influencing the demographic choices of their followers, particularly when they are in a minority. Since religion is a very important component of population studies, the religious characteristics of the population are discussed in all studies which address the demographic characteristics of areas. Religion also plays a very important role in the development of the social, economic, political, and cultural landscape of areas. Therefore, there is no dearth of literature about the religious composition of areas or addressing a particular religion. However, a few studies worth mentioning are:

Krishan (2004) in his study on "Demography of the Punjab (1848-1947)", has devoted a special section to religious composition and noted that it was on the basis of religion that British India was partitioned; and, more pertinently, the partition was specific to only two provinces, Punjab and Bengal.

While highlighting the challenges for the Sikh community in Punjab, Ghuman (2012) has observed that the most serious challenge, in the socio-economic domain, to the Sikh community is to provide access to quality education and health services for all members of the community. The unfavourable sex-ratio is also a major challenge for the community. Shifting the workforce from farm to non-farm sectors and from low-productivity to high productivity employment avenues are among the other imminent challenges.

Through an examination of letters written by Sikh soldiers serving in the British Indian Army during World War I and contemporary documents from within their global religious, legislative, and economic context, (Soboslai 2018) in his study "Sikh Self-Sacrifice and Religious Representation during World War I" highlighted the ways Sikh constructions of sacrifice were created and employed to engender social change in the early twentieth century.

Gosal (1965) in his study on "Religious Composition of Punjab's Population Changes, 1951-61" has noted that the religious 
composition of Punjab's population had undergone significant changes during 1951-1961. The excessive migration of the Sikhs to other Indian states and foreign lands has reduced their proportion in the total population of their home state. The Hindu population on the other hand, has slightly improved its relative strength because of an excess of immigration over emigration.

In his study on "Demographic Dynamism of Punjab, 19712011", Gill (2017) has noted that the sharp fall in the growth of the Sikh population could possibly be attributed to three causes: (i) a rapid reduction in the birth rate, (ii) the greatly accelerated pace of emigration since the early 1990s, and (iii) the large-scale loss of life, particularly of younger adults, during violence stemming from the Punjab turmoil from 1984 to 1995 (Singh 2001).

Similarly, Mangat \& Gill (2019) have also observed that in Punjab, considered to be the Sikh home land, the Sikh population is declining, while all other religious communities have grown. They have further observed that religion emerges as a motivating force towards building a distinct social group to watch over its interests in the wider socio-political space. On the basis of their analysis, they have predicted that Sikhs are likely to be a minority in their home state within two-three decades.

Singh (1988) in her study "Religion and Fertility: A Study in Differentials" has pointed out that the study of religious differentials in fertility is significant because India is a multi-religious society and any variations in the growth rate of different communities would upset the balance and therefore, from a policy point of view, it is necessary to understand the differentials in growth rate.

While discussing the religious composition of Punjab's urban population, 1981 Gill (1986) has mentioned that apart from its key role in understanding of the present socio-political pulse of a region, the study of religious composition also unlocks the past patterns of religious proselytization and migrations.

Singh (1986) has attempted a very exhaustive study on Christianity in India, by highlighting its consolidation during the early centuries, its revival after the coming of the Portuguese, its expansion during British Colonial Rule, its progress after Independence and its distributional patterns in 1981.

While attempting a study on "The Sikh Community in Bangkok Chinatown: Thailand", Courine (1995) has stressed that the Sikhs have done well in the cultural setup of Thailand. While retaining their cultural identity, they have become fully integrated in their adopted society. Although not so large in number, the Sikhs have been successful in attaining a notable socio-cultural and economic visibility in Bangkok.

Ray (2008) in his study on the "Political Role of Religious Communities in the Indian Subcontinent" has discussed in detail the different religion-based policies of the Muslim rulers in northern India for about 700 years prior to the commencement of British supremacy in 1757 . He has also discussed the role played by the leaders of the Hindu and Muslim communities in the Partition of British India in 1947 on the basis of religion, resulting in the massacre of around two million people and the displacement or forced migration of about eighteen million people.

The study on the "Politics of Identity \& Independence: Sikh Political Activism at Home and in the Diaspora" attempted by Mishra (2008) seeks to analyze the complex interconnection between the identity politics of the Sikh community in the diaspora and Sikh homeland politics in India. Building on the history of Sikhism, the paper focuses on the continuity and changes in the nature of political activism of the Sikhs both in the diaspora and homeland in the context of globalization.

In a study on "Religion in Indian Politics: Need to be Value Oriented, Not Power Oriented", Banu (2009) has focused on contemporary issues and conflicts in the Indian polity with reference to the debate over secularism and the use of religion in politics in India. The study also strives to understand the rise of religious controversies and their relationship with politics, economy and society. A detailed analysis is also carried out to capture the variations in the form of social conflicts taking shape in different part of the country and their impact on the future of Indian democracy.

While stressing the need to study the religious composition of India, Gill \& Bhardwaj (2010) have observed that, apart from its significant effect on voting patterns, religious composition also carries its own implications for fertility levels, occupational structure, and migration patterns, particularly in developing countries like India.

Based on a strong database and scientific methodology, lyer \& Shrivastava (2015) have attempted a study on "Religious Riots and Electoral Politics in India". They combined the data on riots with electoral data from state legislature elections and control variables on demographics and public goods' provision to construct a unique panel data set for 16 large states in India over a 21 year period from 1981-2001. They found that riots occurring in the year preceding an election, increases the vote share of the Bharatiya Janata Party by 5 to 7 percentage points in the election.

On the basis of available primary and secondary sources of data, Jodhka (2009) in his study, "Sikhs in Contemporary Times: Religious Identities and Discourses of Development" has attempted to deal with some aspects of the social and economic life of Sikhs in India. He has specifically focused on the internal differences and dynamics of the Sikh population in different parts of the country.

The above review of literature, suggests that there is much scope to attempt a study on the religious composition of India with special reference to Sikh religion. The main thrust of this study therefore, is to highlight the position of the Sikh religion in comparison to the major religious communities of India. The amalgamation of religion with politics in India necessitates an understanding of the disposition of Sikhs on the religious and political landscape of the country.

\section{Results and discussion}

Change in share of population by religion

In 1991, the share of Hindu population in the total population of India was $82.00 \%$ followed by Muslims (12.11\%), Christians $(2.34 \%)$ and Sikhs $(1.94 \%)$. In 2011, the share of Hindu population declined to $79.80 \%$, Christians to $2.30 \%$ and Sikhs to $1.72 \%$, while the share of Muslim population increased to $14.23 \%$. It has been observed that the share of Muslim population at national level recorded a growth rate of $17.51 \%$ during this 20 -year period. The study further reveals that the share of Muslim population is continuously increasing, while the share of all other religious communities is declining and the greatest decline $(-11.34 \%)$ is noticed in the Sikhs population (Table 1).

Hindu, the largest religion of India, experienced a $2.68 \%$ decline in share, while the share of the Christian population declined by $1.71 \%$ from $1991-2011$. The analysis shows that, leaving aside Muslims, all other religious communities have become growth conscious and their growth rate is declining. The Sikhs are exceptionally concerned about their growth, as suggested by the greatest decline in their share during the study period. In the case of Muslims, Anawaruzzaman (2010) has observed that "with increasing education, income and occupational shifts from primary to secondary and tertiary sectors, fertility is found to be decreasing with the lone exception of increasing fertility with income among Muslims". Thus, the share of Muslim population in India is continuously increasing.

Growth of population by religion

Table 2 reveals that the Muslim population recorded the highest growth rate of $24.65 \%$ in $2001-11$, followed by Hindus 
MISCELLANEA GEOGRAPHICA - REGIONAL STUDIES ON DEVELOPMENT

Vol. $25 \cdot$ No. $3 \cdot 2021 \cdot$ pp. 181-187 • ISSN: 2084-6118 • DOI: 10.2478/mgrsd-2020-0055

Table 1. India: Share in Population and Change, By Religion, 1991-2011

\begin{tabular}{|c|c|c|c|c|}
\hline \multirow{2}{*}{ Religion } & \multicolumn{3}{|c|}{ Share in Percentage } & \multirow{2}{*}{$\begin{array}{c}\text { Change in Share } \\
\text { 1991-2011 (\%) }\end{array}$} \\
\cline { 2 - 4 } & $\mathbf{1 9 9 1}$ & $\mathbf{2 0 0 1}$ & $\mathbf{2 0 1 1}$ & 17.51 \\
\hline Muslim & 12.11 & 13.43 & 14.23 & -1.71 \\
\hline Christian & 2.34 & 2.34 & 2.30 & -2.68 \\
\hline Hindu & 82.00 & 80.46 & 79.80 & -11.34 \\
\hline Sikh & 1.94 & 1.87 & 1.72 & \\
\hline
\end{tabular}

Source: Own elaboration based on Census of India data - 1991, 2001 and 2011

Table 2. India: Growth Rate of Population, By Religion, 2001-2011

\begin{tabular}{|c|c|}
\hline Religion & Growth Rate (\%) \\
\hline Muslims & 24.65 \\
\hline Hindus & 16.76 \\
\hline Christians & 15.53 \\
\hline Sikhs & 8.42 \\
\hline
\end{tabular}

Source: Own elaboration based on Census of India data - 2001 and 2011

Table 3. India: Change in Growth Rate of Population, By Religion, 1991-2011

\begin{tabular}{|c|c|c|c|}
\hline \multirow{2}{*}{ Religion } & \multicolumn{2}{|c|}{ Growth Rate (\%) } & Change in Growth \\
\cline { 2 - 3 } & $\mathbf{1 9 9 1 - 2 0 0 1}$ & $\mathbf{2 0 0 1 - 2 0 1 1}$ & Rate (\%) \\
\hline Hindu & 20.35 & 16.76 & -17.64 \\
\hline Muslim & 36.02 & 24.65 & -31.65 \\
\hline Christians & 22.60 & 15.53 & -31.28 \\
\hline Sikhs & 18.18 & 8.42 & -53.68 \\
\hline
\end{tabular}

Source: Own elaboration based on Census of India data - 1991, 2001 and 2011

Table 4. Northwestern India: Share of Total Sikh Population in India, By State/UT, 2011

\begin{tabular}{|c|c|}
\hline State & $\%$ \\
\hline Punjab & 76.82 \\
\hline Haryana & 5.97 \\
\hline Rajasthan & 4.19 \\
\hline Delhi & 2.74 \\
\hline Jammu\& Kashmir & 1.13 \\
\hline Uttarakhand & 1.13 \\
\hline Chandigarh (UT) & 0.66 \\
\hline Himachal Pradesh & 0.38 \\
\hline Total & $\mathbf{9 3 . 0 2}$ \\
\hline
\end{tabular}

Source: Own elaboration based on Census of India data - 2011
(16.76\%), Christians (15.53\%) and Sikhs (8.42\%). Thus, among the major religions, the growth rate of the Sikh population is three times less than that of Muslims and about two times less than recorded by Hindus and Christians respectively. The growth rate of $8.42 \%$ in case of Sikhs is considerably below their estimated natural increase rate of around $12.0 \%$ over the decade (Krishan 2018).

Further, to find out the trend in the growth rate of these religious communities, growth rates for 1991-2001 and 20012011 are calculated and presented in Table 3 . It has been observed that all religious communities have recorded declining trends in their growth rate during the study period. However, it is interesting to note that Hindus recorded the smallest (-17.64\%) trend decline in its growth rate among all the religious groups and it was about two times less than that recorded by Muslims (Table 3). The study suggests that although the growth rate of the Muslim population is highest among all the religious communities, it has shown a declining trend overtime. Thus, taking into account the declining tendency in the growth rate of the Muslim population, the concern of Sangh Pariwar that India will become a Muslim country in the near future, which has caused them to raise the issue of Ghar Wapsi should be reconsidered.

The analysis further reveals that the greatest decline in the growth rate is witnessed by Sikhs $(-53.68 \%)$. The declining trend in the growth rate of the Sikh population is more than three times that recorded by Hindus and about two times more than that registered by Muslims and Christians respectively. Thus, among the major religious groups, Sikhs have witnessed the lowest growth rate of its population and consequently the greatest negative change in their growth rate during the study period. Therefore, the major anxiety among the Sikhs particularly, in the minds of its religious leaders, is the sharp decline in its growth rate considering declining trends in the strength of votes, although the decline in the Sikh population is a symbol of its prosperity which it wants to keep at the cost of its growth. However, as all the country's politics is engineered on the caste and religion vectors, Punjab has the Sikh population at the heart of its calculations (Bains 2015).

\section{Share of Sikh population by state}

Sikhs are now found virtually everywhere. India accounts for about $83 \%$ of the total Sikh population in the world. Within India, about $93 \%$ of the total Sikh population is concentrated in the six northwestern states of Punjab, Haryana, Himachal Pradesh, Rajasthan, Jammu and Kashmir, Delhi (NCT), Uttarakhand and the union territory of Chandigarh (Table 4).

Of the total, about $77 \%$ of the Sikh population lives in Punjab. After Punjab, other major areas of Sikh concentration are the states of Haryana (5.97\%) and Rajasthan (4.19\%). Haryana has been carved out of Punjab; therefore, the Sikh population is comparatively high, while large numbers of Sikhs have migrated to Ganganagar and the adjoining district of Rajasthan where cheap agricultural land became available after the introduction of canal irrigation. Likewise, Delhi, accounting for $2.74 \%$ of the Sikh population has been a preferred city for the educated, businessoriented Sikh community to settle down in after partition.

However, it is surprising to note that Himachal Pradesh, shows the lowest share of the Sikh population $(0.38 \%)$ among all the northwestern states of India, although the Kangra, Lahaul, Spiti and Kulu districts, were parts of the state before its reorganization in 1966. It is mostly because of the mountainous topography of Himachal Pradesh where no agricultural land is available for Punjabis to settle down on; hence the share of the Sikh population is very low in Himachal Pradesh. Even after the partition, no one could migrate to Himachal Pradesh as an Act was passed by the state that prohibits the purchase of agricultural 
Table 5. Northwestern India: Percentage Share of Sikhs in Total Population, By State, 1981-2011

\begin{tabular}{|c|c|c|c|c|c|c|}
\hline State & $\mathbf{1 9 8 1}$ & $\mathbf{1 9 9 1}$ & $\mathbf{2 0 0 1}$ & $\mathbf{2 0 1 1}$ & $\begin{array}{c}\text { Growth Rate } \\
\mathbf{2 0 0 1 - 2 0 1 1}(\mathbf{\%})\end{array}$ & $\begin{array}{c}\text { Growth Rate } \\
\mathbf{1 9 8 1 - 2 0 1 1}(\mathbf{\%})\end{array}$ \\
\hline Punjab & 60.74 & 62.95 & 59.90 & 57.69 & -3.69 & -5.02 \\
\hline Haryana & 6.21 & 5.81 & 5.54 & 4.91 & -11.37 & -20.93 \\
\hline Himachal Pradesh & 1.22 & 1.01 & 1.19 & 1.16 & -2.52 & -4.92 \\
\hline Jammu \& Kashmir & 2.23 & - & 2.04 & 1.87 & -8.33 & -16.14 \\
\hline Delhi & 6.33 & 4.84 & 4.01 & 3.40 & -15.21 & -46.29 \\
\hline Chandigarh & 21.12 & 20.29 & 16.12 & 13.11 & -18.67 & -37.93 \\
\hline Uttarakhand & - & - & 2.50 & 2.34 & -6.40 & -12.41 \\
\hline Rajasthan & 1.44 & 1.47 & 1.45 & 1.27 & -11.80 \\
\hline
\end{tabular}

Source: Own elaboration based on Census of India data - 1981, 1991, 2001 and 2011

land by non-Himchalis. Similarly, although Jammu and Kashmir remained within the Sikh Empire t, the topographical constraints for agriculture did not allow the penetration of Sikhs as a farming community. Even after Independence, the rules did not allow non-Kashmiris to settle in Jammu and Kashmir, hence the share of Sikh population there is very low (1.13\%). Although the availability of agricultural land in Uttarakhand is also lower due to its mountainous topography, the presence of a Sikh population in Uttarakhand is due to the Terai area of the state which remained an attractive destination for Punjabi farmers to settle in; they wanted to enlarge their land holdings due to the cheap availability of agricultural land compared to their home states. Similarly, the union territory of Chandigarh, being small in size, accounted for a very small share of the Sikh population, although Chandigarh is the state capital.

\section{Temporal change in share of Sikh population by state}

In 1981, the highest share of Sikh population among all the religious communities was in Punjab followed by Chandigarh, Delhi, Haryana, Jammu and Kashmir, Rajasthan and Himachal Pradesh respectively (Table 5). From 1981 to 2011, a general trend of declining share of Sikh population in all the states has been noticed. The exceptions were Punjab where, in 1991, the share of Sikh population increased by $3.64 \%$ and Delhi, where the share of Sikh population declined by $-23.54 \%$. This reflected the 1984 anti-Sikh riots in Delhi and in other states from where the Sikh population migrated to Punjab.

During this 30 year period (1981-2011), Delhi recorded the greatest decline $(-46.29 \%)$ in share of Sikh population followed by Chandigarh $(-37.93 \%)$, Haryana $(-20.93 \%)$, Jammu and Kashmir (-16.14\%) and Rajasthan (-11.80\%; Table 5). It is worth noting that despite recording an improvement in the share of Sikh population in 1991, Punjab has recorded a $-5.02 \%$ decline in the share of Sikh population during the period under study. Further, taking last decade of 2001 and 2011 into account, it is found that Chandigarh has recorded the greatest decline in the share of Sikh population $(-18.67 \%)$ even as the state capital. This is followed by Delhi $(-15.21 \%)$, Rajasthan $(-12.41 \%)$, Haryana $(-11.37 \%)$, Jammu and Kashmir $(-8.33 \%)$, and Uttarakhand $(-6.40 \%)$ when compared with a $-3.69 \%$ decline in the share of the Sikh population in Punjab. Such a sharp decline in the share of Sikh population in all these states is due to the declining fertility of the Sikh population and emigration of Sikhs within India or to other countries. Table 6 , which shows the lowest growth rate of
Sikh population among all the religious communities in all of the northwestern states of India also supports this observation.

Population growth by state and religion

It is surprising to note that Chandigarh, the capital of Punjab, has recorded a negative growth rate $(-4.71 \%)$ of its Sikh population between 2001-2011 among all the states under study (Table 6). On the other hand, all other religious groups witnessed a positive growth rate; $14.33 \%$ recorded by Christians, $20.42 \%$ by Hindus and $44.72 \%$ by Muslims (Table 6 ). The negative growth rate witnessed by the Sikh population in Chandigarh is due to the fact that; i) after the development of S.A.S. Nagar (Mohali) on the periphery of Chandigarh, with similar amenities and facilities available in Chandigarh, the city did not remain a preferred city among the Sikhs for settlement; ii) the Sikhs who were employed in Chandigarh and occupying government accommodation left the city after their retirement and settled down in Mohali where land was available at much cheaper rates than in Chandigarh; iii) the number of employees seconded from Punjab to Chandigarh has declined with the passage of time and only include those prefer to work in Chandigarh and who have accommodation on the periphery and where it is possible to commute daily. Thus, the shadow effect of SAS Nagar (Mohali) has checked the growth of the Sikh population in Chandigarh.

Delhi recorded a very low growth rate of $2.69 \%$ of its Sikh population between 2001-2011 against growth of $12.10 \%$, $20.72 \%$ and $32.96 \%$ recorded by Christians, Hindus and Muslims respectively. Growth of Sikh population in Delhi is about 8 times and 12 times less than that recorded by Hindus and Muslims respectively. After the 1984 anti-Sikh riots, Delhi is no longer an attractive place for Sikhs to live, hence it witnessed a very low growth rate of its Sikh population between 2001-2011. The low fertility rate among Sikhs and emigration within India and to other countries are other factors behind the very low growth of the Sikh population in Delhi, while immigration is an important reason for the high growth rate of other religious communities. Likewise, a very low growth rate $(6.24 \%)$ of the Sikh population was recorded by Haryana (Table 6 ). The growth of the Sikh population in Haryana is 3 times, 7 times and 13 times less than that recorded by Hindus, Muslims, and Christians respectively. The Sikh community is not very comfortable in Haryana after the reorganization of Punjab, as a result of which it has emerged as a minority group, with just a $4.91 \%$ share in the total population of the state. The Sikh population of Haryana, in particular, settled 
MISCELLANEA GEOGRAPHICA - REGIONAL STUDIES ON DEVELOPMENT

Vol. 25 • No. 3 • 2021 • pp. 181-187 • ISSN: 2084-6118 • DOI: 10.2478/mgrsd-2020-0055

Table 6. Northwestern India: Growth Rate of Population, By Religion, 2001-2011

\begin{tabular}{|c|c|c|c|c|}
\hline \multirow{2}{*}{ State } & \multicolumn{4}{|c|}{ Growth Rate (\%) } \\
\cline { 2 - 5 } & Muslims & Christians & Hindus & Sikhs \\
\hline Punjab & 40.16 & 18.93 & 18.67 & 9.68 \\
\hline Haryana & 45.66 & 85.22 & 18.84 & 6.24 \\
\hline $\begin{array}{c}\text { Himachal } \\
\text { Pradesh }\end{array}$ & 25.41 & 64.51 & 12.62 & 10.42 \\
\hline $\begin{array}{c}\text { Jammu \& } \\
\text { Kashmir }\end{array}$ & 26.12 & 75.53 & 18.68 & 13.37 \\
\hline Uttarakhand & 38.99 & 39.33 & 16.03 & 11.47 \\
\hline Rajasthan & 29.80 & 32.71 & 20.95 & 6.66 \\
\hline Delhi & 32.96 & 12.10 & 20.72 & 2.69 \\
\hline Chandigarh & 44.72 & 14.33 & 20.42 & -4.72 \\
\hline
\end{tabular}

Source: Own elaboration based on Census of India data - 2001 and 2011

in the districts adjoining Delhi also had to bear the repercussions of the anti-Sikh riots in 1984. Sikhs are also always willing to migrate to other areas whenever they get the chance to enhance their landholding or job opportunities. The low birth rate and emigration of the younger generation of Sikhs from Haryana to other countries is also catching up with the trends and destinations identified by their relatives in Punjab, hence the growth of the Sikh population is low in the state.

The low growth rate of the Sikh population in Rajasthan $(6.66 \%)$ is down to: i) migration of the Sikh population to Rajasthan to improved landholdings has been stopped due to the saturation of the canal irrigated areas of Ganganagar district; ii) the check imposed by the Government of Rajasthan on the purchase of agricultural land by outsiders to settle in the state. Thus, the growth of the Sikh population in Rajasthan is entirely a reflection of the natural growth rate which is lowest among Sikhs.

Even in their home state of Punjab, the growth of the Sikh population is $9.68 \%$ against $18.67 \%, 18.93 \%$ and $40.16 \%$ for Hindus, Christians and Muslims respectively. In other words, the growth of the Sikh population in Punjab is two times less than the growth rate of Hindus and Christians and four times less than that recorded by Muslims. Considering the sub-division of land holding and expenses involved in the rearing of a child, the trend for a single child is fast catching up among Sikhs. Therefore, the growth rate of the Sikh population is very low. It has been reflected in the decline of their Total Fertility Rate (TFR), which has come down from 3.1 in 1991 to below the replacement level of 1.8 in 2011 (Krishan 2018). Chandna (2015) also noted that Punjab has achieved a significant fall in its total fertility rate (TFR) from 2.4 children per woman in 2000 to 1.7 children per woman in 2013 which is even lower than the replacement level of 2.1. Further, due to rampant unemployment in the state and declining agricultural income, large numbers of young students are migrating to other countries like Canada, USA, Australia and Europe on the pretext of higher education and are ultimately settling down in these countries, followed by their friends, relatives and parents.

Apart from the push factors working at home, there are also strong pull factors operating at destinations as these countries have liberalized their immigration policies to attract young talent; initial support is available to new migrants from their relatives and friends. On the other hand, the gap created by the exodus of young, qualified people is gradually being filled by an uneducated/ semi-qualified labour class from other religions from different states, who are migrating and settling in Punjab (Mangat \& Gill 2019; Gosal 1965). During the last decade (2001-2011) the share of Sikh population in Punjab has fallen 2.21 percentage points. If this trend continues, it is expected that Sikhs will become a minority in Punjab within two-three decades. But with the existing accelerating trend of emigration by the young population of reproductive age, the growth rate of the Sikh population is likely to fall further; therefore, there is a possibility that the Sikhs may emerge as a minority group in Punjab by 2031 . However, this will become clearer after the results of the 2021 Census.

The comparatively higher growth rate of the Sikh population in states like Jammu and Kashmir (13.37\%), Uttarakhand $(11.47 \%)$ and Himachal Pradesh (10.42\%) is due to the low base level population; as the share of Sikh population is just $1.87 \%$, $2.34 \%$ and $1.16 \%$ respectively in these states. Thus, there is hardly any possibility that this comparatively higher growth rate of Sikh population is going to lead to an overall improvement in the share of Sikh population in these states.

On the whole, the study reveals that the share of Sikh population and its growth rate is not only less but also declining at a faster rate than all other religious communities under study. This trend is also likely to continue in the future, not only in Punjab but in all other states of India as well. Thus, with the reduction in numerical strength, Sikhs are also losing political magnitude under the existing political scenario in India. The Bharatiya Janata Party, which fights elections in alliance with the Shiromani Akali Dal in Punjab, has started asking for more seats in both assembly and parliamentary elections. The results of the 2021 Census are likely to provide added weight to their demand. The study, therefore, highlights that the Sikh space is gradually declining not just on the religious, but also on the political landscape of India.

\section{Conclusion}

With the increasing penetration of both religion and caste composition in the political environment of India, religious- and caste-based groups are exercising more power as pressure groups in local and regional level elections. It has been noticed that the lower the level of election taking place, the greater is the importance of religious and caste groups on account of their voting strength to participate in elections. Therefore, all the religious leaders start counting their number and share in comparison to other communities as soon as the religious data is released by the Census of India. The study reveals that, at the national level, the number of Muslims is continuously increasing while the numbers of all other religious communities is in decline. The greatest decline is noticed in case of the Sikh population. Even in Punjab, it has also been observed that, among the major religious groups, the Sikhs have witnessed the lowest population growth rate and consequently the greatest decline in their share of population. Considering the declining trend in the share of the Sikh population in Punjab, this study suggests that it may take more than two to three decades before the Sikhs become a minority group even in their home state of Punjab both in number and political strength.

\section{ORCID}

Harwant Singh Mangat (D) https://orcid.org/0000-0002-5003-7261 Lakhvir Singh Gill (1D https://orcid.org/0000-0003-3672-4759 Shaik Iftikhar Ahmed (1D https://orcid.org/0000-0003-1771-1565 
Ahmad, A 1999, Social Geography, Rawat Publications, New Delhi.

Anwaruzzaman, AKM 2010, 'Differentials in fertility by religion in Darjeeling District', Population Geography, vol. 32, pp. 16-36.

Bains, K 2015, 'Why Sikhs ought to be haooy, not worried', The Tribune 30 August. Available from: <https://www. tribuneindia.com/news/archive/features/why-sikhs-ought-tobe-happy-not-worried-126229>. [12 September 2020].

Banu, Z 2009, 'Religion in Indian Politics: Need to be value oriented, not power oriented', The Indian Journal of Political Science, vol. 70, no.3, pp. 705-718.

Chandna, RC 2006, Geography of Population, Kalyani Publishers, New Dehli.

Chandna, RC 2015, 'Punjab-Haryana Region: Growth of Population: 2001-2011', Punjab Geographer, vol. 11, pp. 103-106.

Courine, P 1995, 'The Sikh Community in Bangkok Chinatown: Thailand', Population Geography, vol. 17, no.1,2, pp. 17-25.

Ghuman, RS 2012, 'The Sikh Community in Indian Punjab: Socio-economic challenges', Journal of Punjab Studies, vol. 19, no.1, pp. 87-110.

Gill, MS 1986, 'Religious composition of Punjab's urban population, 1981', Population Geography, vol. 18, no.1,2, pp. 38-49.

Gill, MS 2017, 'Demographic Dynamism of Punjab, 1971-2011', Economic \& Political Weekly, vol. 52, no.3, pp. 26-29.

Gill, MS \& Bhardwaj, PD 2010, 'The religious composition of India's population', Sarjana, vol. 25, no.2, pp. 61-76.

Godbole, M 2019, 'Right question, wrong answer', The Indian Express 9.

Gosal, GS 1965, ‘Religious composition of Punjab's population changes, 1951-61', Economic \& Political Weekly, vol. 17, no.4, pp. 119-123.

Guru, G 2019, 'Interrogating the citizenship (amendment) bill', Economic \& Political Weekly, vol. 54, no.49, pp. 7-8.

Hausing, KKS 2019, 'Not about Hindu and Muslim', The Indian Express 19 December.

Heredia, RC 2015, 'Secularism in a pluri-religious society, the constitutional vision', Economic \& Political Weekly, vol. 50, no.14, pp. 51-59.

lyer, S \& Shrivastava, A 2015, 'Religious Riots and electoral politics in India', IZA Discussion Paper, no. 9522, University of Cambridge, United Kingdom. Available from: <http://ftp. iza.org/dp9522.pdf>. [15 September 2020].

Jodhka, SS 2009, 'Sikhs in contemporary times: Religious identities and discourses of development', Sikh Formations, vol. 5, no.1, pp. 1-22.

Katju, M 2015, 'The politics of Ghar Wapsi', Economic and Political Weekly, vol. 50, no.1, pp. 21-24.

Khanna, RM \& Garg, B 2019, 'Congress will not spare those behind Bargari, Says Rahul', The Tribune 1.

Krishan, G 2004, 'Demography of the Punjab (1848-1947)', Journal of Punjab Studies, vol. 11, no.5, pp. 77-92.

Krishan, G 2018, 'Slowing down of growth rate of Sikh population in India', Population Geography, vol. 40, no.1,2, pp. 77-81.

Mangat, HS \& Gill, LS 2019, 'Sikhs are loosing ground in their Home State: A geographical analysis', Punjab Geographer, vol. 15, pp. 52-63.

Mishra, BK 2008, 'Politics of identity \& independence: Sikh political activism at home and in the diaspora' in Political Role of Religious Communities in India, eds JK Ray \& AB Roy, Institute for Security and Development Policy, Stockholm-Nacka, pp. 71-81.
Mishra, G 1994, 'Economics or communalism in India' in Religious Fundamentalism in Asia. ed. VD Chopra, Gian Publishing House, New Delhi, p 43-59.

Parkash, A 2019, 'Uneasy nation, lines within', The Indian Express, $\mathrm{p} 13$.

Ray, JK 2008, 'Political role of religious communities in the Indian Subcontinent' in Political Role of Religious Communities in India, eds JK Ray \& AB Roy, Institute for Security and Development Policy, Stockholm-Nacka, pp. 43-49.

Roy, A 2019, 'The Citizenship (Amendment) Bill, 2019 and the Aporia of Citizenship', Economic \& Political Weekly, vol. 54, no.49, pp. 28-34.

Express News Service 2019, 'NRC, new citizenship law over my dead body, says Mamta Banerjee', The Indian Express 17 December. Available from: <https://indianexpress.com/ article/india/nrc-new-citizenship-law-over-my-dead-bodymamata-banerjee-6170684/>. [15 September 2020].

Singh, D 2015, 'Reinventing Agency, sacred geography and community formation: The case of displaced Kashmiri Pandits in India' in The Changing World Religion Map, eds SD Brunn \& DA Gilbreath, Springer Dordrecht Heidelberg, New York, London.

Singh, KP 1988, 'Religion and fertility: A study in differentials', Population Geography, vol. 10, no.1,2, pp. 18-27.

Singh, M 1986, 'Christianity in India: A temporal-spatial view', Population Geography, vol. 8, no.1,2, pp. 82-98.

Singh, P 2001, 'Punjab terrorism: Truth still uncovered', Economic \& Political Weekly, vol. 36, no.40, pp. 3829-3831.

Soboslai, J 2018. "Sikh self-sacrifice and religious representation during World War I." Religions, vol. 9, no.2, pp. 55-73.

Teltumbde, A 2015, 'Ghar Wapsi, welcome to the Hellhole Hinduism', Economic \& Political Weekly, vol. 50, no.1, pp. 10-11.

Yadav, S 2019, 'A Time to unite', The Indian Express 18 December. Available from: <http://14.139.58.147:8080/ jspui/bitstream/123456789/1519/1/106.pdf>. [12 September 2020]. 